DOI: $10.15643 /$ libartrus-2017.4.6

\title{
Intercultural communication: hot topics and prospects for change in non-linguistic universities
}

\author{
(C) E. P. Zheltova1, L. G. Yusupova ${ }^{2 *}$ \\ ${ }^{1}$ The Bonch-Bruevich Saint-Petersburg State University of Telecommunications \\ 22 Bolshevikov Avenue, 193232 Saint Petersburg, Russia. \\ 2Ural State Mining University \\ 30 Kuibyshev Street, 620144 Yekaterinburg, Russia.
}

*Email: lyalyax@bk.ru

\begin{abstract}
In the article, the development of intercultural readiness of university students for intercultural communication by using the developed multifunctional model is considered. The definition of intercultural readiness of students, the units of the developed model, as well as the content of each unit are presented in detail. Moreover, the components of development of readiness for intercultural communication are fully described. The aim of this work is to assess both the approaches of the multifunctional model and the pedagogical conditions of development of students' intercultural readiness. The authors analyze the results of technical universities students' survey aimed at finding out the respondents' levels of intercultural readiness.
\end{abstract}

Keywords: intercultural readiness, intercultural environment, intercultural communication, multifunctional model, pedagogical conditions, development.

\section{Introduction}

Today working life entails some degree of intercultural interaction for most people: in professional sphere, in education, in travelling, etc. We are all foreigners now. Our world needs cross-cultural talent and intercultural competence - a series of interlocking skills and attitudes that influence how a person deals with people from other cultures. Translating talent into competence depends on intercultural readiness [3]. Intercultural readiness requires specialists to be open to change and to seek actively information about what needs changing. Change requires more than adding new information to existing knowledge. It means being open to reconsider what one has taken for granted. Intercultural readiness is not about playing games, it is about understanding, communicating, and cooperating with people from other cultures effectively and honestly. Therefore, the variety of the world, cultures, and languages states the need for the development of intercultural readiness of students to become interculturally effective.

\section{Materials and Methods}

The socio-pedagogical essence of intercultural readiness means: orientation of a student to the participation in intercultural communication; definite level of language knowledge and development of the communicative skills allowing to manage various communication situations, to estimate relevantly the representatives of another culture, to predict their behavior, to establish with them the proper relations, to interact successfully taking into account the situation conditions. We can define the development of students' intercultural readiness for communication as the many-sided overall process characterized by the availability of social, ethnic-psychological, and pedagogical factors. The concept of "intercultural readiness" is stated by us as the ability of university students to enhance 
their potential efforts by using the gained intercultural experience, knowledge, and skills, also by making their own decisions in the framework of intercultural communication [12-13]. One of the key aspects of intercultural readiness is the ability to stay flexible and alert in dealing with other cultures [3].

In our research, we will study a modeling method for development of university students' intercultural readiness for communication just to provide any changes both in educational process for training highly qualified specialists capable to adapt to various values in a situation of intercultural dialogue and in refusal of culture-educational monopoly concerning the nations and the people.

The multifunctional model of the development of students' intercultural readiness for communication designed by us consists of a target unit, a theory-based methodological unit, organizational unit, conceptual unit, technological, and results-estimated ones [13]. This model provides understanding of dialectic dependence between elements of the studied issue. The external function of the model, namely the development of students' readiness to intercultural communication acts as the central backbone unit. This function is carried out by joint activity of university professors and students. Fig. 1 represents the developed multifunctional model of university students' intercultural readiness for communication.

The target unit is presented by the existence of a specific goal, i.e. the development of university students' intercultural readiness for interaction and includes the following functional components: emotional, cognitive, value motivational, process activity-based one. The theory-based methodological unit of the model is based on the various approaches to the organization of the development of university students' intercultural readiness for interaction.

They are socio-cultural, linguopedagogical, ethnopedagogical, learner-centered, functional, explanatory, critical approaches, intercultural readiness. Socio-cultural approach is intended for training intercultural communication in the context of social and pedagogical dominants of pedagogical science in the civil world such as consent, socialization, humanization when the foreign-language training itself is provided on the basis of intercultural dialogue $[1,2,6]$.

Linguopedagogical approach can lay the foundation for the new intercultural paradigm aimed at the study of meanings of various cultures and their adequate perception, interpretation, at harmonious education and development of future specialists [14]. Ethnopedagogical approach provides the usage of national traditions, culture training standards of international communication taking into account the national characters and it is directed to the development of the universal and ethical values, and moral and spiritual ones.

We consider the application of learner-centered approach as the set of personal characteristics providing the future specialists to perform their duties adequate to the requirements of their activity.

Functional approach reveals the specifics of culture influence to communication. The result of functional approach is the theory of communication adaptation. It explains the fact that in the processes of intercultural communication the people often change their models of communicative behavior, thus adapting to the communication models of partners. This approach allows studying styles of influence in different cultures [6].

Explanatory approach assumes that the environment around a person is not alien as it is created by the person himself. We do not consider the students to occupy a neutral position in intercultural communication as a political (ideological) position on perception of "ins and outs" cultures. In our opinion it is a case of a diplomatic position that is very important for a successful communication. The acceptance of a neutral position itself is a political and ideological state of affairs for language; it's 
not a neutral phenomenon. As it is noted in our work, the purpose of explanatory approach is in understanding and describing, but not in predicting a behavior of a person. Therefore, in this case the contingencies cannot be considered during the research processes. In this case, it is possible to speak only about acceptance and interpretation of this or that situation.

The methods of anthropology and linguistics are widely used in this approach: role-playing games, participant observation, and others. The investigations of intercultural communication based on the explanatory approach reveal that communication rules of different community are based on cultural values and beliefs of this individual group [4, 7].

Critical approach includes many provisions of explanatory approach, but the accent in the researches of intercultural communication is made on the study of communication conditions such as situations, surrounding environment, and others. The historical context of communication is considered firstly by this approach. The explanation of human behavior and their change of life becomes the purpose of learning intercultural communication using this kind of approach. The main method of critical approach is the analysis of texts (telecasts, video records, press publications).

Intercultural readiness approach works with intercultural competence offering students a clear structure for becoming more effective across cultures, that is, to better connect to people from other cultures, perform more effectively and efficiently in achieving task-related goals and find intercultural interaction more enjoyable. The main method of this approach is the perspective on diversity. Diversity acts as a source of learning and integration [3].

We believe the combination of approaches mentioned in our paper makes intercultural interaction successful and harmonious.

\section{Findings}

In our research, the structure of the organizational unit is presented by a set of pedagogical conditions for development of students' intercultural readiness for interaction such as:

- realization of students' intercultural potential;

- application of project-based learning with the purpose of the development of students' readiness for intercultural communication in the multicultural environment.

Russian scientists determine the intercultural potential as the integrative characteristic of the personality having both the humanistic values, broad knowledge in areas of other cultures and communicative creativity, a flexibility, empathy, tolerance [8-9, 11]. Intercultural potential is closely connected with the concept "empathy", i.e. an ability to put oneself to the place of another, to look at everything with another's eyes, to feel his state, and to consider all this in the behavior and following acts.

The second pedagogical condition assumes the use of a method of projects as the development tool of intercultural readiness of students for communication in the conditions of the multicultural environment of higher-learning institutions in Russia. The method of projects is not essentially new in the international pedagogy. It appeared at the beginning of last century in the USA. In our opinion, the project represents an optimum form of the organization of intercultural interaction of students for the development of readiness for intercultural communication when training a foreign language with the application of means of telecommunication.

The telecommunication intercultural project represents the interaction of students of different cultures in a foreign language organized by telecommunication aids. The cornerstone of a method of projects are the development of cognitive skills of students, abilities to self-designing knowledge, abilities for being well-versed in information space, the development of critical and creative thinking. 
In the framework of teaching foreign languages, this method can be used within curriculum material practically in any theme. The main thing is to formulate a problem for discussion in the course of studying the theme. The method of projects has a number of advantages in comparison with other traditional methods, namely it increases educational, cultural, cognitive activity of students, develops their independence, creates the atmosphere of trust and support, provides constant feedback, increases interest and motivation in implementation of intercultural communication.

The conceptual unit of the developed model includes the principles and functions on the development of students' intercultural readiness for interaction and communication.

Thus, we have used the following principles:

- the principle of "dialogue of cultures" as a means of simultaneous training both a foreign language and foreign culture by comparison with the native language and culture;

- the principle of multiculturalism in educational systems demanding the protection and multiplication of all variety of cultural values, norms, behavior samples, and forms of activity;

- the principle of cultural relativism, which demands the respect and tolerance to the norms, values, and types of behavior in foreign cultures; assumes the practical relation to the culture of every people; forms aspiration to understand culture from inside; focuses students to occupy a neutral position on perception of "ins and outs" cultures [10].

- the principle of complementarity, which considers a regional component, reflects interrelation of ethnic groups and cultures in the conditions of multilingualism and the multicultural environment of Russia [5].

The following functions for development of students' intercultural readiness for interaction and communication have been determined in this research:

- developing function is directed to the formation of the intercultural person ready to perceive the representative from different culture as an equal partner in communication, capable not to be afraid of meeting with "alien", and trying to make a contact with the purpose of effective mutual understanding, to absorb elements of various cultures, and to be open to further intercultural improvement;

- informative function is directed to acquisition and enrichment of information about native and foreign cultures; to elimination of stereotypes, formation of positive relation to the "alien" people;

- value and orientation-based function is directed to free orientation in intercultural environment, promotes understanding of native and foreign people as carriers of national values; makes a person be capable not only to participate in the intercultural dialogues, but also to comprehend their interrelation, universal values and human essence;

- regulatory function is directed to adequate mutual understanding of participants in the course of intercultural communication; to ability to reflex actions and to realize own position in order to develop new strategies of behavior, including skills to harmonize and govern the relations with representatives of other cultures at the cross-cultural level to gain the most productive interaction.

The technological unit is presented by the methods and techniques directed to the realization of a set of pedagogical conditions including the general training resources (training programs, education guidances, didactic materials) and specific ones (computers, projectors, Internet, email). It provides various training methods (projects method, self-assessment method, simulation method, role-games method, heuristic method, method of biographic reflections, portfolio method). 
The result-estimated unit is presented by the application of some levels (low, average, high) indicators and a technique of psychological and pedagogical diagnostics. The result of this model application is directed to transition to higher level of the development of students' readiness for intercultural communication.

Thus, the presented multifunctional model acts as the means of organization of the practical actions aimed at the development of students' intercultural readiness for interaction and communication. That is why it has a pragmatic character.

\section{Discussion}

Having studied the existing ideas on the readiness for various aspects of professional activity, having defined the intercultural readiness as the complex, integrative, personal formation; as the system of mental states, personal features and characteristics, which contributes to the successful intercultural communication, we tried to determine the following components in the structure of intercultural readiness:

- emotional component. It includes manifestation of positive and negative emotions at acquaintance to other cultures; positive emotions (a pride for own culture), negative ones (cultural shock); empathic ones (desire to understand the other world, aspiration to change own point of view);

- cognitive component. It helps to systematize information on the uniform conceptual basis, in the uniform logic. The interaction of the categories "culture", "education" and "information" is represented as essential because it is the knowledge in the form of information that can be used in educational systems as an instrument for ensuring a freedom for actions and subjective manifestations in culture. It provides mastering not only a certain level of knowledge, but also formation of a cultural outlook, and also a possibility of their continuous replenishment and regeneration. This component is defined by the professional orientation which is the leading motive of informative activity of students;

- motivation and value-based component. It assumes the existence of positive attitude, interests, needs, the sets providing steady motivation to intercultural communication. Its axiological aspect is connected with the problems of value-based reflection of an individual culture and education;

- process activity-based component. It provides the direct solution of theoretical and practical problems, the new target-making, new principles, new pedagogical technologies in education. The abilities to use some new means, methods, technologies allow building the innovative concepts of training and education considering ethnocultural requirements and needs of a student.

We assume the sufficient integrity of these components as an indicator of high level of professional psychological readiness of students of non-linguistic universities to their working practice, their activity and creativity. The system of the marked components represents the integral structure as its separate elements are in functional dependence. The interaction of these components proceeds from the account of specific features of future specialists' work activity, variety of the relations and communication, system of valuable orientations, possibilities, creative self-realization of a person.

In the table below, we present both the structural components of the development of students' intercultural readiness for professional communication across cultures and their main indicators. 
Functional components and their indices for the development of intercultural readiness of students are presented.

\begin{tabular}{l|l}
\hline Structural components & Essential indices \\
\hline Emotional & Manifestation of emotions at acquaintance with other cultures: \\
& - positive (a pride for own culture); \\
- negative (cultural shock); \\
- empathic (desire to understand other people, aspiration to change \\
own point of view, relativism of ethnocultural views).
\end{tabular}

From the point of view of the composition of levels of university students' intercultural readiness it is necessary to highlight the following points:

- high level of readiness (those students possess: high degree of knowledge in the field of intercultural communication; ability to come into contact with representatives of other cultures; high index of emotional etiquette possession, nonverbal means of communication; ability to manage own emotional state in the process of communication);

- average level of readiness (those students are expected to have partial formation the intercultural skills, the partial level of knowledge in the field of intercultural communication, average communicative self-control in communication; they're unable to apply sign systems of communication in a situation of interaction).

- low level of readiness (those students feel the same difficulties in communication, as students with the average level, but they're more categorical in perception and assessment of the foreign culture representatives; show negative motives for studying other culture etiquette, lack of readiness and ability to dialogue of cultures and to interaction, low communicative selfcontrol and creativity in communication).

Functional components are closely connected with each other and play an important role in recognition of practical importance of the structure-semantic model of development of students' readiness for intercultural communication. Earlier it was confirmed during the experimental work conducted in the Ural State Mining University (Yekaterinburg), the Saint Petersburg State University of Trade and Economics [12-13]. 
The test results of complex impact of mentioned conditions for the development of intercultural readiness of students of non-linguistic language specialties are presented in Table 2 and 3.

Table 2

Pilot stage for determination of the students' levels in the experimental (E) and control (C) groups is given.

\begin{tabular}{|c|c|c|c|c|c|c|c|c|c|}
\hline \multirow{3}{*}{ Groups } & \multirow{3}{*}{ Stages } & \multicolumn{6}{|c|}{ Levels } & \multirow{3}{*}{$\begin{array}{l}\text { Average } \\
\text { point }\left(\mathrm{P}_{\mathrm{a}}\right)\end{array}$} & \multirow{3}{*}{$\begin{array}{l}\text { Efficiency } \\
\left.\text { Ratio ( } \mathrm{R}_{\mathrm{eff}}\right)\end{array}$} \\
\hline & & \multicolumn{2}{|c|}{ low } & \multicolumn{2}{|c|}{ middle } & \multicolumn{2}{|c|}{ high } & & \\
\hline & & amount & $\%$ & amount & $\%$ & amount & $\%$ & & \\
\hline \multirow{2}{*}{ E } & starting & 19 & 54.29 & 12 & 34.29 & 4 & 11.42 & 1.57 & 0.98 \\
\hline & final & 5 & 14.29 & 14 & 40.00 & 16 & 45.71 & 2.31 & 1.25 \\
\hline \multirow{2}{*}{$\mathrm{C}$} & starting & 17 & 51.52 & 12 & 36.36 & 4 & 12.12 & 1.61 & - \\
\hline & final & 11 & 33.33 & 16 & 48.48 & 6 & 18.19 & 1.85 & - \\
\hline
\end{tabular}

Table 3

Dynamics of development of students' intercultural readiness is shown.

\begin{tabular}{|c|c|c|c|c|c|}
\hline \multirow{3}{*}{ Groups } & \multicolumn{5}{|c|}{ Indicators of total gain $(G)$} \\
\hline & \multicolumn{3}{|c|}{ G according to the levels (in \%) } & \multirow{2}{*}{$\mathrm{GPa}$} & \multirow{2}{*}{$G_{\text {Reff }}$} \\
\hline & low & middle & high & & \\
\hline $\mathrm{E}$ & -40.00 & +5.71 & +34.29 & +0.74 & +0.27 \\
\hline $\mathrm{C}$ & -18.19 & +12.12 & +6.07 & +0.24 & - \\
\hline
\end{tabular}

During experimental work, the number of students with the high level of intercultural readiness has increased by $34.29 \%$ and with the middle level by $5.71 \%$. In the control group, these ratios have raised by $6.07 \%$ and $12.12 \%$ respectively. The number of students with the low level of intercultural readiness has decreased by $18.19 \%$. It means that students' readiness is progressing; however, the transition to a higher level happens much more slowly. In general, the number of the students having the low level of development of intercultural readiness has decreased by $40.00 \%$ [12].

We can conclude that those changes happened in the levels of development of students' intercultural readiness in the experimental group are not caused by the casual reasons, but due to the consequence of complex realization of the pedagogical conditions mentioned within the developed multifunctional model of development of students' intercultural readiness for intercultural communication.

To sum up, we believe it is on condition of integration of the components mentioned above marked with "high level" when it is possible to speak about intercultural readiness of students which could contribute to their future professional communication more effectively across cultures.

\section{Conclusion}

Thus, according to a stated objective of our investigation, we made an attempt to study the development of students' intercultural readiness for future communication across cultures by using the created multifunctional model. Conclusions are put forward that the prospects of using the multifunctional model can lead to the essential increase of level of students' readiness for intercultural communication and their intercultural competence in general.

\section{References}

1. Baryshnikov N. V. Parameters of training intercultural communication // Inostrannye yazyki v shkole. 2002. No. 2. Pp. 29-38. 
2. Bespalko V. P. System-based methodological support of teaching and educational process for training the specialists. Moscow: The higher school, 1989. 141.

3. Brinkmann U., O. van Weerdenburg. Intercultural Readiness: Four Competences for Working Across Cultures. Springer Press. 2014. URL: http://books.google.ru/books?isbn=1137346981.

4. Byram M., Nicols A., Stevens D. Developing Intercultural Competence in Practice. Bristol: Multilingual Matters, 2001. 283 p.

5. Granatov G. G. Method of a complementarity in development of concepts (pedagogy and psychology). Magnitogorsk: MGSU, 2000. 195 p.

6. Grushevitskaya T. G., Popkov V. D., Sadokhin A. P. Bases of intercultural communication: The textbook for higher education institutions. Moscow: UNITY-DANA, 2003. $352 \mathrm{p}$.

7. Gudycunst W. Cultural variability in communication // Communication Research. 1997. Vol. 24. No. 4. Pp. 327-348.

8. Lewis R. D. Business cultures in the international business. From collision to mutual understanding. M.: Business, 2001. $448 \mathrm{p}$.

9. Musina O. V. Development of intercultural potential of students of higher education institution in the course of foreign language learning. (Doctoral dissertation). Magnitogorsk, 2004. 155 p. URL: http://www.dissercat.com/ content/razvitie-mezhkulturnogo-potentsiala-studentov-vuza-v-protsesse-izucheniya-inostrannogo-yazyk.

10. Ter-Minasova S. G. Languages and intercultural communication. Moscow: SLOVO, 2000. 624 p.

11. Yusupov I. M. Psychology of empathy: Theoretical and practical aspects. (Doctoral dissertation). Saint Petersburg: St. Petersburg State University, 1995. 252 p. URL: http://www.dissercat.com/content/psikhologiya-empatii.

12. Yusupova L. G. Development of readiness of students of non-linguistic specialties of higher education institution for intercultural communication. (Doctoral dissertation). Chelyabinsk, 2008. Pp. 45-57. URL: http://search. rsl.ru/ru/record/01004112893.

13. Yusupova L. G., Zheltova E. P. The Structure-functional Model of Development of Students' Readiness for Intercultural Communication // British Journal of Education, Society \& Behavioural Science. 2016. Vol. 18. No. 2. Pp. 1-8. https://doi.org/10.9734/BJESBS/2016/28678. URL: http://www.sciencedomain.org/review-history/16395.

14. Zheltova E.P. Development of intercultural competence of technical university students in the process of foreign language teaching: (Doctoral dissertation). Magnitogorsk, 2006. Pp. 71-103. URL: http://www.dissercat.com/content/razvitiemezhkulturnoi-kompetentsii-studentov-tekhnicheskogo-universiteta-v-protsesse-izuche. 
DOI: 10.15643/libartrus-2017.4.6

\title{
Межкультурная коммуникация: актуальное направление и перспективы развития в неязыковых вузах
}

\author{
(C) Е. П. Желтова ${ }^{1}$, Л. Г. Юсупова" \\ ${ }^{1}$ Санкт-Петербургский государственный университет телекоммуникаций \\ им. проф. М. А. Бонч-Бруевича \\ Россия, 193232 г. Санкт-Петербург, проспект Большевиков, 22. \\ 2 Уральский государственный горный университет \\ Россия, 620144 г. Екатеринбург, улица Куйбышева, 30. \\ *Email: lyalyax@bk.ru
}

Данная статья посвящена развитию межкультурной готовности студентов университета на основе разработанной многофункциональной модели. Краткий вводный абзац посвящен определению межкультурной готовности студентов. Затем подробно анализируются блоки (содержание каждого блока) разработанной модели, основательно описываются компоненты развития межкультурной готовности. Авторы анализируют результаты определения уровней развития межкультурной готовности студентов технических университетов.

Ключевые слова: межкультурная готовность, межкультурная среда, межкультурная коммуникация, многофункциональная модель, подходы к организации, уровни межкультурной готовности.

Просьба ссылаться на эту работу как: Zheltova E. P., Yusupova L. G. Intercultural communication: hot topics and prospects for change in non-linguistic universities // Liberal Arts in Russia. 2017. Vol. 6. No. 4. Pp. 339-348. 